\title{
Lower annual fecundity in long-distance migrants than in less migratory birds of temperate Europe
}

\author{
Bruno Bruderer • Volker Salewski
}

Received: 19 March 2008/Revised: 1 October 2008/Accepted: 7 October 2008/Published online: 19 November 2008

(C) Dt. Ornithologen-Gesellschaft e.V. 2008

\begin{abstract}
We use widely supported handbook data on annual fecundity (clutch size $\times$ annual number of normal broods) to obtain indications related to the relative costs of long-distance migration compared to lower levels of migratoriness. Our examples show that the yearly production of eggs in congeneric passerines of similar size from temperate Europe is lower in long-distance migrants than in their less migratory relatives. The same tendency shows up in a more heterogeneous sample of non-passerines. In most passerines and in one among five pairs of nonpasserines, this is due to longer breeding periods allowing a higher number of clutches in the less migratory species in spite of a tendency towards larger clutches in the passerine long-distance migrants. If both migratory types have only one clutch (as in one species pair of the passerines and in four non-passerine pairs) the trend towards larger clutches was reversed between the two types. The higher fecundity of the less migratory species suggests that wintering under harsh conditions may be more expensive than trans-Sahara migration among similar species. In keeping with this result, Ortolan and Rock Buntings (Emberiza hortulana and E. cia) breeding syntopically (and, in the 1980s, still in relatively stable populations) in an inner Alpine valley provide a well-studied example illustrating the high longevity of the migrants compared to the relatively short life span of the residents.
\end{abstract}

Communicated by A. Hedenström.

B. Bruderer $(\bowtie)$

Swiss Ornithological Institute, 6204 Sempach, Switzerland

e-mail: bruno.bruderer@vogelwarte.ch

V. Salewski

Max-Planck-Institut für Ornithologie, Vogelwarte Radolfzell, Schloss Möggingen, Schlossallee 2, 78315 Radolfzell, Germany
Keywords Costs of migration versus residency Clutch size - Number of clutches - Reproductive output . Short-distance migrants

\section{Introduction}

Increased annual reproductive success at higher latitudes was often used to support the idea that tropical species evolved migration towards higher latitudes to capitalise on seasonally abundant resources allowing higher reproductive output (e.g. Rappole and Jones 2002). In a less teleological manner, one may argue that birds having dispersed to seasonal areas may increase their reproductive output to the level allowed by the seasonal flush of resources within the limits given by their life history. For the low productivity season, they have two options: they may stay close to the breeding grounds, implying adaptation to reduced resources and increased energy demands during winter, or they may migrate to lower latitudes, facing mortality risks of migration. Migration is commonly considered to be a dangerous venture. This general idea was confirmed, e.g. by Sillet and Holmes (2002), who found that, in an American longdistance migrant, most adult mortality occurred during migration. However, highest mortality also seems to occur in resident birds during the non-breeding season. Newton (1998) considers stable populations with negligible numbers of non-breeders to be winter-limited. Ricklefs (1980), corroborating Ashmole's hypothesis that clutch size of passerine birds increases with the seasonality of resources relative to population density, found that the latter is usually regulated through density-dependent mortality during the non-breeding season. Martin (2004) confirms that annual mortality and fecundity are strongly correlated, balancing each other in stable populations. 
If populations were balanced over time, and nonbreeding seasons decisive for population regulation, mortality during the non-breeding season would reflect the costs of non-breeding survival, i.e. the costs of staying close to the breeding area during the non-breeding time, or alternatively the overall costs of migration.

Kipp (1943) pointed out that long-distance migrants among German passerines and pigeons usually have only one clutch, while most species with a longer presence on the breeding grounds have two or even more clutches with nearly equal numbers of eggs. He concluded that mortality was higher during winter in temperate areas compared to the tropical winterquarters. Three large-scale statistical comparisons (Mönkkönen 1992; Martin 1995; BöhningGaese et al. 2000) included this question while studying the interrelationships of various life history traits and environmental conditions. Due to the inclusion of a wider variety of species, they provided partially differing and more complex results than the earlier study. In order to have the biology of the included species closer at hand for interpretation, we decided to address the issue again by concentrating on a narrow selection of similar species, thus avoiding as much as possible the influence of differences in body size, nest type, nest location, nestling development, habitat, latitude and continent, all of which had been found to influence clutch size and fecundity (Böhning-Gaese et al. 2000).

We suggest that comparing the annual fecundity of similarly sized closely related species breeding in the same temperate area provides clarifying information on the relative costs of residency and migration.

\section{Methods}

The Handbuch der Vögel Mitteleuropas (Glutz von Blotzheim and Bauer 1966-1997) and its updated Kompendium (Bauer et al. 2005) provide broad and bestsupported information on the breeding biology of birds in central Europe. From the very detailed information in the original handbook, Bauer et al. (2005) retained the essential values. The handbook data on breeding biology are derived from relatively large areas, often from large-scale nest card programs and thus reflect more the situation in meta-populations than in specific subpopulations with potentially unbalanced immigration/emigration.

We scanned Bauer et al. (2005) with the aim of finding pairs or groups of congeneric bird species of similar size from central Europe differing in their migratory behaviour in such a way that trans-Saharan migrants (long-distance migrants) could be compared with short-distance migrants or residents. This was possible for seven pairs or groups of passerines (Table 1). According to these selection criteria,
Alaudidae, Hirundinidae, Acrocephalidae, Sylviidae and others could not be included due to the lack of either longdistance migrants or residents in central Europe (not only within a genus, but even when the condition of intra-generic comparison was dropped). For non-passerines, the application of the strict criteria was only possible for three pairs (Anas, Falco, Streptopelia; Table 2). To complement the non-passerine sample, we lowered the threshold for inclusion by considering non-congeners of similar size within the families Phasianidae, Strigidae and Picidae. For these species, we checked whether the yearly production of eggs (average clutch size $\times$ number of normal broods, excluding replacement clutches) differs between long-distance migrants and less migratory species. The data, preferably from Switzerland and southern Germany, were taken from Bauer et al. (2005): (1) the migratory status; (2) weight $(\mathrm{g})$, in some cases Bauer et al. (2005) provide ranges of weights per month instead of averages (this without sample size, but obviously sample sizes were large, when splitting into temporal sub-samples was possible); (3) size of mainly first clutches; (4) range of normal clutch numbers per season; (5) the resulting number of eggs per season, multiplying the average clutch size by the number of clutches per season (and a value considering smaller second clutches); and (6) the duration of the breeding season in months for the Swiss Lowlands and southern Germany (Tables 1 and 2).

\section{Results}

For passerines, the main difference in annual fecundity between the compared long-distance migrants and less migratory species is the normally lower number of clutches of trans-Saharan migrants due to the reduced time available on the breeding grounds (Table 1). The total number of eggs produced per season by similarly sized congeneric passerines is higher in the species with lower levels of migratoriness, in spite of their normally smaller clutch size. As an exception, the number of clutches in the Lanius species is not only constrained to one in the migrant species, but also in the resident $L$. excubitor. Strikingly, the resident has the larger clutch in this case, supporting the idea that non-breeding mortality would be higher in residents than in migrants breeding in the same temperate areas. The shrike data in Table 1 are derived from Bauer et al. (2005). According to the data in Glutz von Blotzheim (1964), the difference between the two shrike species appears to be even greater, with an average of $6.8(n=45)$ for $L$. excubitor and $5.0(n=10)$ for $L$. minor. The migrant Lanius collurio was not included in Table 1, because it is only half the weight of the other two species; but its reproductive output is practically the same as $L$. minor. 
Table 1 Annual reproductive output of congeneric passerines of similar size, breeding in central Europe, but having different migratory strategies $^{\mathrm{a}}$ (data compiled from Bauer et al. 2005 and Glutz von Blotzheim 1964)

\begin{tabular}{|c|c|c|c|c|c|c|c|c|c|}
\hline \multirow[t]{2}{*}{ Species } & \multirow{2}{*}{$\begin{array}{l}\text { Migratory } \\
\text { status }\end{array}$} & \multicolumn{2}{|c|}{ Weight in grams $(n)^{\mathrm{c}}$} & \multicolumn{3}{|c|}{ Clutch size $(n)^{\mathrm{d}}$} & \multirow{2}{*}{$\begin{array}{l}\text { Clutch } \\
\text { number }^{\mathrm{e}}\end{array}$} & \multirow{2}{*}{$\begin{array}{l}\text { Eggs per } \\
\text { season }^{f}\end{array}$} & \multirow{2}{*}{$\begin{array}{l}\text { Breeding } \\
\text { seasong }^{\mathrm{g}}\end{array}$} \\
\hline & & Males & Females & Range & Average & $n$ & & & \\
\hline Lanius minor & $\mathbf{L}$ & $50.4(12)$ & $51.8(9)$ & $4-7$ & 5.5 & 28 & 1 & 5.5 & 2.5 \\
\hline L. excubitor & $\mathrm{S}, \mathrm{R}$ & $68.5(11)$ & $66.0(11)$ & $4-7$ & 6.1 & 56 & 1 & 6.1 & 4.0 \\
\hline Emberiza hortulana & $\mathbf{L}$ & $22.9(19)$ & $22.7(10)$ & $3-6$ & 4.7 & 24 & 1.1 & 5.2 & 2.3 \\
\hline E. schoeniclus & $\mathrm{S}, \mathrm{R}$ & $19.7(27)$ & $17.9(18)$ & $4-5$ & 4.6 & 174 & 2 & $9.2(9.0)$ & 3.6 \\
\hline E. cia & $\mathrm{S}, \mathrm{R}$ & $22.9(24)$ & $21.1(18)$ & $2-5$ & 3.9 & 74 & 2.2 & 8.6 & 4.3 \\
\hline E. cirlus & $\mathrm{S}, \mathrm{R}$ & $26.1(11)$ & $25.6(14)$ & $2-5$ & 3.8 & 41 & 2.2 & 8.4 & 4.0 \\
\hline E. citrinella & $\mathrm{R}, \mathrm{S}$ & $30.4(130)$ & $29.2(154)$ & $3-5$ & 4.0 & 131 & 2 & 8 & 4.3 \\
\hline $\begin{array}{l}\text { Phylloscopus } \\
\text { trochilus }\end{array}$ & $\mathbf{L}$ & $9.1(61)$ & & $4-8$ & 6.3 & 42 & 1.1 & 6.9 & 2.6 \\
\hline$P$. sibilatrix & $\mathbf{L}$ & $9.8(27)$ & $10.1(27)$ & $5-8$ & 6.3 & 26 & 1.1 & 6.9 & 2.3 \\
\hline P. bonelli & $\mathbf{L}$ & $8.5(209)$ & & $5-6$ & 5.2 & 26 & 1 & 5.2 & 2.5 \\
\hline$P$. collybita & $\mathrm{S}$ & $8.2(43)$ & $8.4(74)$ & $4-6$ & 5.7 & 61 & 1.8 & $10.3(9.4)$ & 3.5 \\
\hline Saxicola rubetra & $\mathbf{L}$ & $16.7(64)$ & $16.1(59)$ & $5-7$ & 6.0 & 24 & 1 & 6 & 3.0 \\
\hline S. torquata & $\mathrm{S}$ & $17.2(13)$ & $16.9(11)$ & $4-6$ & 5.4 & 55 & 2.1 & 11.3 & 4.5 \\
\hline Phoenicurus phoenic. & $\mathbf{L}$ & $17.7-19.0$ & $16.4-16.9$ & $5-7$ & 6.3 & 203 & 1.1 & 6.9 & 3.0 \\
\hline P. ochruros & $\mathrm{S}$ & $16.0(255)$ & & $4-6$ & 4.8 & 119 & 1.8 & 8.6 & 4.0 \\
\hline Motacilla flava & $\mathbf{L}$ & $16.5(66)$ & $15.4(59)$ & $5-6$ & 5.8 & 44 & 1.1 & $6.4(6.2)$ & 2.2 \\
\hline M. alba & $\mathrm{S}$ & $22.9(26)$ & & $5-6$ & 5.6 & 87 & 2 & 11.2 & 3.6 \\
\hline M. cinerea & $\mathrm{R}$ & $16.8(17)$ & & $4-6$ & 5.3 & 181 & 2 & 10.6 & 4.0 \\
\hline Anthus trivialis & $\mathbf{L}$ & $21.7(81)$ & $21.3(78)$ & $3-6$ & 5.0 & 134 & 1.5 & $7.5(7.2)$ & 3.3 \\
\hline A. pratensis & $\mathrm{S}$ & \multicolumn{2}{|c|}{$17.3-18.9$} & $4-6$ & 4.3 & 105 & 1.8 & 8.3 & 4.0 \\
\hline Mean $\pm \mathrm{SD}^{\mathrm{h}}$ & $\mathbf{L}$ & & & & & & & $6.3 \pm 0.79$ & $2.65 \pm 0.4$ \\
\hline Mean $\pm \mathrm{SD}^{\mathrm{h}}$ & $\mathrm{S}, \mathrm{R}$ & & & & & & & $9.3 \pm 1.24$ & $4.0 \pm 0.33$ \\
\hline
\end{tabular}

${ }^{a}$ Long-distance migrants are highlighted in bold

${ }^{\text {b }}$ L: Long-distance migrant (with Sahara crossing), S: short- or medium-distance migrant (without Sahara crossing), R: mainly resident. The status of birds from central Europe is indicated, the main behaviour first

c Average weights (separately for males and females where known) from central Europe (mainly autumn or breeding time; elevated winter data in italics); sample size in parentheses. Values for Phoenicurus phoenicurus and Anthus pratensis show the range of monthly means

${ }^{\mathrm{d}}$ Range of most frequently observed clutch sizes (excluding extremes and replacement clutches), average values of mainly first clutches from Switzerland or southern Germany, and sample size. Average values for Emberiza hortulana and E. cia derived from a detailed study in an inner Alpine valley in Switzerland are lower due to the inclusion of small replacement clutches (see text)

e The most frequently observed clutch number (excluding replacement clutches) from Switzerland or southern Germany. If relevant numbers of additional clutches occur, this is indicated by a corresponding decimal

${ }^{f}$ Product of average clutch size $\times$ clutch number. Numbers in parentheses are estimates considering smaller clutches in second broods

g Duration of breeding season in months (usual start of egg-laying to usual fledging of late broods)

${ }^{\mathrm{h}}$ Excluding shrikes, considering calendar effect (reduction of annual fecundity by smaller second clutches)

Ortolan Bunting (E. hortulana) and the Rock Bunting (E. cia) are a well-studied pair of passerines with reliable survival data due to high breeding-site fidelity in an optimal habitat confined to the central parts of a dry inner Alpine valley, the Wallis. The Swiss populations of Rock Buntings showed no negative trend between the mid-1970s and 2003, while the Ortolan Buntings declined in most parts of Switzerland before and during this period, remaining at a high level until the mid-1990s only in a restricted population confined to the Wallis (Maumary et al. 2007). During the years 1982-1988, Keusch (1991) and his colleague P. Mosimann intensively studied syntopically breeding populations of the two species in the rocky steppes of the central Wallis. The study confirms that, during the study period, both populations remained relatively stable (close to 30 pairs in the Ortolan, and at 1418 pairs in normal years for the Rock Bunting, dropping to 8 after a harsh winter, but recovering in the following year). The average fluctuation rate in the number of established pairs between years was only $2.3 \%$ in the Ortolan and $9.3 \%$ in the Rock Bunting. With the approval of the author, we draw the following data from his 
Table 2 Annual reproductive output of closely related non-passerines of similar size, breeding in central Europe, but having different migratory strategies $^{\mathrm{a}}$ (data compiled from Bauer et al. 2005)

\begin{tabular}{|c|c|c|c|c|c|c|c|c|}
\hline \multirow[t]{2}{*}{ Species } & \multirow{2}{*}{$\begin{array}{l}\text { Migratory } \\
\text { status }^{\mathrm{b}}\end{array}$} & \multicolumn{2}{|c|}{ Weight in grams ${ }^{c}$} & \multicolumn{2}{|c|}{ Clutch size $^{\mathrm{d}}$} & \multirow{2}{*}{$\begin{array}{l}\text { Clutch } \\
\text { number }^{\mathrm{e}}\end{array}$} & \multirow{2}{*}{$\begin{array}{l}\text { Eggs per } \\
\text { season }^{f}\end{array}$} & \multirow{2}{*}{$\begin{array}{l}\text { Breeding } \\
\text { season }^{\mathrm{g}}\end{array}$} \\
\hline & & Males & Females & Range & Average & & & \\
\hline Anas querquedula & $\mathbf{L}$ & 396 & 372 & $7-11$ & 8 & 1 & 8 & 4 \\
\hline A. crecca & $\mathrm{S}, \mathrm{R}$ & 360 & 340 & $8-11$ & 9 & 1 & 9 & 4 \\
\hline Coturnix coturnix & $\mathbf{L}$ & 94 & 116 & $7-13$ & 11.6 & 1 & 11.6 & 4 \\
\hline Perdix perdix & $\mathrm{R}$ & 200 & 230 & $10-20$ & 15.7 & 1 & 15.7 & 4.5 \\
\hline Falco subbuteo & $\mathbf{L}$ & 193 & 237 & $2-4$ & 2.7 & 1 & 2.7 & 3.5 \\
\hline F. tinnunculus & $\mathrm{S}, \mathrm{R}$ & 200 & 260 & $4-6$ & 5.5 & 1 & 5.5 & 5 \\
\hline Streptopelia turtur & $\mathbf{L}$ & \multicolumn{2}{|c|}{$100-180$} & 2 & 2 & 1.5 & 3 & 3.2 \\
\hline S. decaocto & $\mathrm{R}$ & \multicolumn{2}{|c|}{$125-196$} & 2 & 2 & 3 & 6 & $7+$ \\
\hline Otus scops & $\mathbf{L}$ & 83 & 98 & $3-5$ & 4 & 1 & 4 & 3.5 \\
\hline Athene noctua & $\mathrm{R}$ & 180 & 200 & $3-5$ & 4.1 & 1.1 & 4.5 & 5 \\
\hline Glaucidium passerin.. & $\mathrm{R}$ & 59 & 69 & $4-7$ & 5.2 & 1 & 5.2 & 3.5 \\
\hline Jynx torquilla & $\mathbf{L}$ & \multicolumn{2}{|c|}{$30-50$} & $7-10$ & 9 & 1.3 & 11.7 & 2.8 \\
\hline Dryobates minor & $\mathrm{R}$ & \multicolumn{2}{|c|}{$16-26$} & $5-7$ & 5.9 & 1 & 5.9 & 3.8 \\
\hline Dendrocopos medius & $\mathrm{R}$ & 59 & 59 & $5-6$ & 5.4 & 1 & 5.4 & 3.8 \\
\hline
\end{tabular}

${ }^{a}$ Long-distance migrants are highlighted in bold

${ }^{\mathrm{b}}$ L: Long-distance migrant (with Sahara crossing), S: short- or medium-distance migrant (without Sahara crossing), R: mainly resident. The status of birds from central Europe is indicated, the main behaviour first

${ }^{c}$ Average weights (separately for males and females where known) from central Europe

${ }^{\mathrm{d}}$ Range of most frequently observed clutch sizes (excluding extremes and replacement clutches) and average for central Europe

e The most frequently observed clutch number (excluding replacement clutches). If relevant numbers of additional clutches occur, this is indicated by a corresponding decimal

${ }^{\mathrm{f}}$ Product of average clutch size $\times$ clutch number

g Estimated duration of breeding season in months (usual start of egg-laying to fledging of late broods)

unpublished $\mathrm{PhD}$ thesis. The one-brooded Ortolan Bunting had an average clutch size of $4.36 \pm 0.74(n=159)$, combined with an average return rate of $77 \%$ (!) in adult males and $41 \%$ in females. The average clutch size of the two-brooded Rock Bunting was $3.89 \pm 0.56(n=74)$ (thus about 7.8 eggs per season), combined with an average return rate of $39 \%$ in adult males and $26.5 \%$ in females. Third broods (as observed in other areas) did not occur in these summer-hot rocky steppes. The difference between the two species with respect to seasonal productivity is, however, additionally increased by a higher breeding success in the Rock Bunting (70\% successful broods due to excellently camouflaged nests) compared to $48.5 \%$ fledged broods in the Ortolan. In contrast to the Ortolan, no breeding period losses were observed in the Rock Bunting. Based on intense year-round observations, Keusch (1991) confirms that severe mortality of Rock Buntings occurs during the non-breeding period. In contrast, the high return rate of Ortolan males indicates extremely low mortality on migration (a feature that may be concealed in females due to dispersal). The age composition of the two populations early in the breeding period reflects this differential nonbreeding mortality: In the Rock Bunting, the proportion of first-year males was about $61 \%$, in the Ortolan less than 46\%. Among 846 ringed Rock Buntings, only 8 were recovered at an age of $\geq 3$ years, and only 2 at $\geq 4$ years, whereas 655 ringed Ortolan Buntings provided at least 35 males with a minimum age of 3 years, 18 with $\geq 4,9$ with $\geq 5$, and 5 with $\geq 6$ years. The two bunting populations are special due to the relative isolation of the Ortolan population and the low migratoriness of the Rock Buntings. Keusch (1991) mentions an unpublished diploma thesis (Schuphan 1972) on Rock Buntings in western Germany with higher average return rates than the Wallis population, but similarly high variation among years due to variation in winter conditions. The lower annual mortality seems to go along with higher migratoriness of the German population.

Our sample of non-passerines is less homogeneous than that of passerines; some of the selected pairs are not from the same genus or differ in size, others in feeding or breeding ecology. Important differences in the number of clutches exist only for the doves, where the clutch size is usually confined to two eggs. In spite of these difficulties, Table 2 confirms that the long-distance migrants tend to produce fewer eggs per season than the corresponding species with lower levels of migratoriness. Among the four 
one-brooded species pairs (the small ducks, owls, falcons and Phasianidae), we observe the same tendency as in the shrikes, the less migratory species having the larger clutch. An important exception is observed in the small resident woodpeckers having a lower yearly fecundity than the migrant Wryneck Jynx torquilla (see "Discussion”).

\section{Discussion}

Our very restricted comparison of "comparable" cases confirms in principle the idea of Kipp (1943) who stated that the number of eggs produced annually is lower (on average, half) in the usually one-brooded long-distance migrants compared to the usually two-brooded short-distance migrants or non-migrants in Europe. Contrary to his statement on generally equal clutch sizes of migrants and residents, our more precise indication of passerine clutch sizes suggests that the clutches of the one-brooded longdistance migrants are usually slightly larger than those of closely related less migratory species with more than one brood. On the other hand, in one-brooded species pairs, the less migratory species tend towards larger clutches. It appears that there is a trade-off between two strategies, one based on compensating high winter mortality by high annual production, the other based on avoiding harsh conditions by long-distance migration combined with relatively low fecundity in a short breeding season.

We agree with Kipp's (1943) conclusion that (at least for the species from central Europe considered) migration seems to involve less mortality than over-wintering near the breeding grounds. While Kipp (1943) found similar clutch sizes in long-distance migrants and less migratory birds, our data suggest that the clutches of birds wintering in temperate areas are smaller than those of closely related long-distance migrants if they are multi-brooded, but larger if they are one-brooded.

The example of the woodpeckers emphasizes the importance of restricting the selection of species pairs to ecologically and systematically similar species to keep potential differences in factors such as breeding ecology or differential mortality at a minimum. Martin (1995) found that non-excavating hole-nesters (like the Wryneck) had the largest clutches among all the compared nest sites, while the pure excavators had the lowest annual fecundity (and highest adult survival rates). As a potential explanation, he generalised a hypothesis already proposed by Kipp (1943) for the Wryneck, suggesting that the dependence of non-excavators on existing holes for nesting, which are limited in availability, increases reproductive effort once a nest site is obtained.

Hirundines had been excluded from Table 1 because there are no resident species to the north of the Alps due to their feeding strategy as aerial hunters. But they are also special because they stay in temperate areas roughly 1 month longer than most other long-distance migrating passerines, and thus have the potential to rear more than one brood per season. The extreme among them is the Barn Swallow Hirundo rustica, which normally rears two, sometimes even three broods, and has a yearly adult survival rate of only $30-40 \%$ (Turner 2006), and high juvenile mortality. About $50 \%$ of young birds die during the first 3 weeks after fledging (Grüebler 2007); afterwards their survival rate tends to approach that of adults, thus resulting in about $20 \%$ survivors at the end of the first year. Aerial hunters are also special cases in the detailed statistical analysis of Martin (1995), where they appear as outliers with extremely low relative adult survival rates and high fecundity.

Mönkkönen (1992), comparing life history traits of Palaearctic and Nearctic migrant passerines with those of non-migrants, found that long-distance migrants had lower body mass and a smaller number of broods than more sedentary birds. While the lower number of clutches is in accordance with our findings (at least for taxa that are not restricted to one brood), the weight difference was excluded in our comparison by the selection of similarly sized species (except in the Quail/Partridge pair). The higher weight of residents in Mönkkönen's sample can be explained by the large size of typical non-migrants (such as corvids) and short-distance migrants (such as thrushes), a feature that may improve their capability to survive low temperatures. Mönkkönen (1992) found the expected difference in mean annual survivorship between long-distance migrants and more sedentary birds only when he confined the test to a within-family comparison in the eastern Nearctic, thus emphasizing the importance of phylogenetic constraints. It appears that the heterogeneity of the sample was too large to find such differences in Europe.

Martin (1995), studying avian life history evolution in relation to nest sites, nest predation, and food in American passerines and woodpeckers, stated (p. 115) that migratory classification did not influence annual fecundity, except when phylogeny was controlled. When phylogeny was controlled, residents and short-distance migrants had higher annual fecundity than NearcticNeotropical migrants within a nest site and habitat type.

Böhning-Gaese et al. (2000), including all land bird species of Europe and North America in their analysis, confirmed a strong phylogenetic effect on clutch size and fecundity. The impact of the phylogenetic distance matrix on the outcome of their multivariate permutational analyses was, however, that small and specific effects were not readily visible. Over the whole spectrum of land birds, they found (in partial agreement with our restricted comparison) fewer broods in long-distance migrants than in less 
migratory birds, but they also found smaller clutches in the highly migratory birds, while our data suggest smaller clutches of the long-distance migrants if their less migratory counterparts are also restricted to one clutch, but larger clutches if the less migratory relatives can reach higher fecundity by more than one clutch. We agree with their conclusion that many of the differences between studies depend on the diversity of bird species included, strengthening our idea to do a restricted comparison of closely related and ecologically similar species, which allows consideration of deviating particularities in the biology of the birds.

Our carefully chosen species-pairs (or groups) from central Europe show that annual fecundity is higher in residents and short-distance migrants than in long-distance migrants, either due to larger clutches or more than one brood in the less migratory species. This leads to the challenging hypothesis that overall costs of long-distance migration may be lower than the costs of over-wintering at temperate latitudes.

\section{Zusammenfassung}

Geringere Zahl der jährlich produzierten Eier bei

Langstreckenziehern im Vergleich zu wenig

ausgeprägten Zugvögeln gemäßigter Breiten Europas

Wir benutzen breit abgestützte Handbuchdaten zur jährlichen Nachwuchsproduktion (Gelegegröße x Anzahl Normalgelege pro Jahr), um Hinweise auf die relativen Kosten von Langstreckenzug im Vergleich zu wenig ausgeprägtem Zug zu erhalten. Unsere Beispiele zeigen, dass die Jahresproduktion von Eiern bei mitteleuropäischen Singvögeln derselben Gattung und von ähnlicher Größe bei Langstreckenziehern kleiner ist als bei ihren weniger ausgeprägt ziehenden Verwandten. Dieselbe Tendenz zeigt sich in einer heterogeneren Stichprobe von Nicht-Singvögeln. Bei den meisten Singvögeln und bei einem unter fünf Paaren von Nicht-Singvögeln beruht dies auf längerer Brutzeit und dadurch erhöhter Zahl der Gelege bei den wenig ziehenden Arten, trotz einer Tendenz zu größeren Gelegen bei den ausgeprägt ziehenden Singvögeln. In den Fällen, in denen bei beiden Zugtypen nur ein Gelege produziert wird (wie bei einem Singvogelpaar und vier Nicht-Singvogelpaaren), war die Tendenz zu größeren Gelegen zwischen den beiden Zugtypen umgekehrt. Die größere Nachwuchsproduktion bei wenig ziehenden Arten stützt die Idee, dass unter vergleichbaren Arten das Überwintern in gemäßigten Breiten teurer sein könnte als Trans-Sahara-Zug. Ortolan und Zippammer (Emberiza hortulana und E. cia), die syntop (und in den 1980-iger Jahren noch mit relativ konstanten Beständen) in einem inneralpinen Tal brüteten, sind ein gut untersuchtes Artenpaar, dass eindrücklich die Langlebigkeit des Langstreckenziehers gegenüber der hohen Sterblichkeitsrate des Teilziehers illustriert.

Acknowledgments We thank Michael Schaub and Beat NaefDaenzer for carefully reading the text, Peter Keusch and Paul Mosimann for allowing us to use their data on buntings and providing additional oral information. Elisabeth Gillis and two unknown reviewers provided valuable suggestions for improvement.

\section{References}

Bauer H-G, Bezzel E, Fiedler W (2005) Das Kompendium der Vögel Mitteleuropas, 3 vols. Aula, Wiebelsheim

Böhning-Gaese, K, Halbe B, Lemoine N, Oberrath R(2000) Factors influencing the clutch size, number of broodsand annual fecundity of North American and European landbirds. Evol Ecol Res 2:823-839

Glutz von Blotzheim UN (1964) Die Brutvögel der Schweiz. Aargauer Tagblatt, Aarau

Glutz von Blotzheim UN, Bauer KM et al (eds) (1966-1997) Handbuch der Vögel Mitteleuropas. Aula, Wiesbaden, 14 vols

Grüebler MU (2007) Time constraints of breeding twice. On the fitness relevance of timing reproduction and post-fledging parental investment in the barn swallow (Hirundo rustica). Thesis, University of Zurich

Keusch P (1991) Vergleichende Studie zu Brutbiologie, Jungenentwicklung, Bruterfolg und Populationsökologie von Ortolan Emberiza hortulana und Zippammer E. cia im Alpenraum, mit besonderer Berücksichtigung des unterschiedlichen Zugverhaltens. PhD Dissertation, Universität Bern

Kipp FA (1943) Beziehung zwischen dem Zug und der Brutbiologie der Vögel. J Ornithol 91:144-153. doi:10.1007/BF01967665

Martin TE (1995) Avian life history evolution in relation to nest sites, nest predation, and food. Ecol Monogr 65:101-127. doi: $10.2307 / 2937160$

Martin TE (2004) Avian life-history evolution has an eminent past: does it have a bright future? Auk 121:289-301. doi:10.1642/ 0004-8038(2004)121[0289:ALEHAE]2.0.CO;2

Maumary L, Valloton L, Knaus P (2007) Die Vögel der Schweiz. Schweizerische Vogelwarte, Sempach, und Nos Oiseaux, Montmollin

Mönkkönen M (1992) Life history traits of Palaearctic and Nearctic migrant passerines. Ornis Fenn 69:161-172

Newton I (1998) Population limitation in birds. Academic Press, London

Rappole JH, Jones P (2002) Evolution of Old and New World migration systems. Ardea 90:525-537

Ricklefs RE (1980) Geographical variation in clutch size among passerine birds: Ashmole's hypothesis. Auk 97:38-49

Schuphan I (1972) Zur Biologie und Populationsdynamik der Zippammer (Emberiza c. cia). Unveröffentlichte Diplomarbeit, Universität Mainz

Sillet TS, Holmes RT (2002) Variation in survivorship of a migratory songbird throughout its annual cycle. J Anim Ecol 71:296-308. doi:10.1046/j.1365-2656.2002.00599.x

Turner A (2006) The barn swallow. Poyser, London 